Saint Louis University School of Law

Scholarship Commons

All Faculty Scholarship

1997

Night Landings on an Aircraft Carrier: Hospital Mergers and Antitrust Law

Thomas L. Greaney

Follow this and additional works at: https://scholarship.law.slu.edu/faculty

Part of the Antitrust and Trade Regulation Commons, Banking and Finance Law Commons, and the Health Law and Policy Commons 


\title{
Night Landings on an Aircraft Carrier: Hospital Mergers and Antitrust Law
}

\author{
Thomas L. Greaney†
}

The sole consistency that I can find is that in litigation under Section 7, the Government always wins.

-Justice Potter Stewart 1

\section{INTRODUCTION}

Justice Stewart's 1966 dictum about the inevitability of government success in challenging mergers under Section 7 of the Clayton Act held true for another fifteen years or so. In the early 1980 s, however, federal enforcement agencies, the Department of Justice (DOJ) and the Federal Trade Commission (FTC), began to find the federal courts less hospitable to antitrust merger cases as more sophisticated economic inquiries and changing proof burdens complicated the task of identifying anticompetitive mergers. Indeed, since the early $1980 \mathrm{~s}$, the government has lost more litigated merger cases than it has won and has come under criticism from some quarters for becoming gun shy and not adequately policing the wave of consolidations that have occurred over the past decade. ${ }^{2}$

Hospital mergers, however, are a different story. Until two years ago, the government rode a streak of important victories in federal courts and FTC administrative proceedings, ${ }^{3}$ and had obtained consent decrees from scores of hospitals that had

† Professor of Law, Saint Louis University School of Law; B.A., 1970, Wesleyan University; J.D., 1973, Harvard University Law School.

1 United States v. Von's Grocery Co., 384 U.S. 270, 301 (1966) (Stewart, J., dissenting).

2 See Arthur Austin, Antitrust Reaction to the Merger Wave: The Revolution v. the Counterrevolution, 66 N.C. L. REV. 931,944 (1988).

3 See Federal Trade Comm'n v. University Health, Inc., 938 F.2d 1206, 1225 (11 th Cir. 1991); United States v. Rockford Mem'l Corp., 898 F.2d 1278, 1286 (7th Cir. 1990); Hospital Corp. of Am. v. Federal Trade Comm'n, 807 F.2d 1381, 1393 (7th Cir. 1986), cert. denied, 481 U.S. 1038 (1987); Federal Trade Comm'n v. Columbia Hosp. Corp., No. 93-30-CIV FTM-22D, 1993 WL 183557 (M.D. Fla., preliminary injunction issued May 21, 1993); In re American Med. Int'l, Inc., 104 F.T.C. 1, 239 (1984). But see United States v. Carilion Health Sys., 707 F. Supp. 840, 849 (W.D. Va.), aff'd, 892 F.2d 1042 (1989) (holding that the government failed to prove that the planned merger would constitute unreasonable restraint of trade); In re Adventist Health System/West, 5 Trade Reg. Rep. (CCH) 1 23,591, at 23,255 (Aug. 1, 1994) (FTC opinion holding that the evidence did not support the relevant geographic markets alleged in the Commission's complaint). 
announced plans to merge. 4 Antitrust enforcers under both Republican and Democratic administrations placed scrutiny of the structure of health care industry markets at the top of their agendas. ${ }^{5}$ Critics argued that, if anything, it was too easy for the government to prevail in these cases because almost any hospital merger in small- or medium-sized communities would run afoul of concentration benchmarks used to assess the competitive effects of mergers. ${ }^{6}$ That all changed abruptly when three federal district courts (one affirmed by a circuit court of appeals) refused to grant preliminary injunctions in challenges to hospital mergers. ${ }^{7}$ Because all three cases involved relatively isolated markets in which the merging parties faced few (if any) competing hospitals in their immediate area, these cases seemed like sure winners for the government, especially given the favorable precedent that had developed from its successful litigation over the years. ${ }^{8}$

The somewhat surprising outcomes of the recent hospital merger cases reflect the convergence of several cross currents in antitrust law and the health care industry. The title of this Article expresses the author's thesis that courts deciding hospital merger cases are asked to make exceedingly fine-tuned appraisals of complex economic relationships. Further, these decisions require factual judgments regarding what the future may hold in an industry undergoing revolutionary change. Like pilots landing at night aboard an aircraft carrier, courts are aiming for a target that is small, shifting and poorly illuminated.

\section{ANTITRUST MERGER LAW AND ITS APPLICATION TO HOSPITAL ACQUISITIONS}

\section{A. MERGer ANALYSis UNDER THE Clayton ACt}

Section 7 of the Clayton Act, enacted in 1914 and amended in 1950, outlaws mergers whose effect "in any line of commerce or . . . in any section of the country ... may be substantially to lessen competition, or to tend to create a monopoly."9 Congress complicated the judiciary's task by adopting a standard, supported by clear expressions of legislative intent, that (1) contemplates a prospective examination of competitive effects; (2) focused on probabilities, not certainties; and (3) aimed at

4 See 2 John J. Miles, Health Care \& Antitrust LaW $\S 12: 1$, at 12-3 n.4 (1993).

5 See, e.g., Anne K. Bingaman, The Importance of Antitrust in Health Care, Speech Before the University of Utah College of Law (Oct. 5, 1994), in 4 MILES, supra note 4, app. E46-1, at App. E46-3 (1996) (speech given as the Assistant Attorney General, U.S. Department of Justice); Charles F. Rule, Health Care and Antitrust Enforcement: The Buyer's Eye-View, Speech Before the Group Health Association of America (Feb. 28, 1989), in 4 M1LES, supra, app. E14-1, at App. E14-1 (speech given as the Assistant Attorney General, Antitrust Division, U.S. Department of Justice).

6 See Gloria J. Bazzoli et al., Federal Antitrust Merger Enforcement Standards: A Good Fit for the Hospital Industry?, 20 J. HEALTH POL. POL'Y \& L. 137, 149 (1995); Fredric J. Entin et al., Hospital Collaboration: The Need for an Appropriate Antitrust Policy, 29 WAKE FOREST L. REV. 107, 115-16 (1994); David L. Glazer, Clayton Act Scrutiny of Nonprofit Hospital Mergers: The Wrong Rx for Ailing Institutions, 66 WASH. L. REV. 1041, 1055 (1991).

7 See Federal Trade Comm'n v. Butterworth Health Corp., 946 F. Supp. 1285, 1303 (W.D. Mich. 1996); Federal Trade Comm'n v. Freeman Hosp., 911 F. Supp. 1213, 1228 (W.D. Mo.), aff'd, 69 F.3d 260, 273 (8th Cir. 1995); United States v. Mercy Health Servs., 902 F. Supp. 968,989 (N.D. Iowa 1995), vacated as moot, 107 F.3d 632, 634 (8th Cir. 1997).

8 See, e.g., Freeman Hosp., 69 F.3d at 268-72 (discussing precedent); Mercy Health, 902 F. Supp. at 975-87 (same).

915 U.S.C. $\$ 18$ (1996). 
arresting anticompetitive concentration "in its incipiency."10 These aspects of merger cases, coupled with the complexity of economic issues under investigation, necessarily render the inquiry more speculative and uncertain than those involved in most other areas of the law. Indeed, because of this focus, legal scholars have stressed the need for sensible presumptions, proof burdens and precedential guidance to cabin the inquiry and avoid speculative, standardless judicial decision making. 11 Unfortunately, the recent trend in the case law has been in the opposite direction. ${ }^{12}$

\section{Presumptive Illegality}

The basic paradigm set forth by the Supreme Court in its 1963 United States v. Philadelphia National Bank decision guides the antitrust law regarding horizontal mergers and acquisitions-i.e., those involving two firms operating in the same product and geographic markets. ${ }^{13}$ The first steps consist of defining the relevant product and geographic markets in which the merging parties compete, ${ }^{14}$ making market definition a necessary predicate for finding a violation of section 7 of the Clayton Act.15 The Court found that Congress had mandated an inquiry into the substantiality of the potential anticompetitive effects which in turn necessitates a determination of the market affected.16 Next, the Court established a rule of presumptive illegality for mergers creating a "significant increase in the concentration of firms" within the market and producing a merged entity with an "undue percentage share" of the market. ${ }^{17}$ The Court found the presumption of illegality based on market share and concentration data sufficient to warrant enjoining the merger "in the absence of evidence clearly showing that the merger is not likely to have such anticompetitive effects."'18

The presumption-shifting approach of Philadelphia National Bank notably left little room for asserting justifications for the merger-only salutary, procompetitive effects in the relevant market may be considered-and placed a difficult burden on defendants to overcome the presumptive force of the government's statistical case. ${ }^{19}$ However, in its most recent word on the subject, United States v. General Dynamics Corp., the Supreme Court held that concentration/market-share data could be rebutted by post-acquisition evidence showing that the market data on which the government relied did not adequately reflect defendant's competitive position. ${ }^{20}$ Some

10 See Brown Shoe Co. v. United States, 370 U.S. 294, 315-23 (1962); see also Alan A. Fisher \& Robert H. Lande, Efficiency Considerations in Merger Enforcement, 71 CAL. L. REV. 1580, 159193 (1983) (discussing legislative history of the Clayton Act).

11 See Philip E. AREeda \& HeRbert HovenkaMP, ANTITRUST LAw 1905 'h, at 751-53 (Supp. 1996); 4 Phillip AREeda \& DONAld F. TURNER, ANTITRust LAw 9 905, at 14-21 (1980).

12 See infra notes 20-21 and accompanying text.

13 See United States v. Philadelphia Nat'l Bank, 374 U.S. 321, 356 (1963).

14 See id. at 356.

15 See id. at 362 .

16 See id. at 363 .

17 See id. at 364 (stating that competition is clearly threatened when the combined share of merging banks constitutes over $30 \%$ of the market and the concentration level of the five largest banks constitutes $78 \%$ of the market).

18 Id.

19 See id. at 363 (observing that defendants must produce evidence clearly showing that the merger would not have an anticompetitive effect).

20 See United States v. General Dynamics Corp., 415 U.S. 486, 501 (1974). See also United States v. Marine Bancorporation, Inc., 418 U.S. 602, 603 (1974), in which the Supreme Court, without explanation, reiterated the Philadelphia National Bank presumptive rule but did not state that 
lower courts have broadly interpreted General Dynamics as revising the Philadelphia National Bank approach by moderating the strength of the presumption and allowing for rebuttal based on nonstructural factors. ${ }^{21}$

The approach of the federal enforcement agencies 22 has been somewhat inconsistent. On the one hand, in litigation the agencies sometimes stress the strong presumptive rule that the Supreme Court has never overruled.23 On the other hand, as part of their litigation strategy, agencies usually introduce detailed economic and testimonial proof in their case-in-chief, essentially refuting the defendants' rebuttal evidence on the feasibility of collusion or unilateral exercise of market power. ${ }^{24}$ As a practical matter, the force of the presumption is watered down considerably. Moreover, the federal Horizontal Merger Guidelines (Merger Guidelines or Guidelines), ${ }^{25}$ which articulate the framework the agencies apply in analyzing mergers and making prosecutorial case selection decisions, all but abandon ${ }^{26}$ the burden-shifting presumptions that result from market-share and concentration data.27 Instead, the

defendant's rebuttal evidence needed to clearly establish that the merger will not have anticompetitive effects.

21 In United States v. Baker Hughes Inc., then-judge Clarence Thomas viewed the effects of General Dynamics as undermining almost completely the presumptive force of statistical evidence:

Imposing a heavy burden of production on a defendant would be particularly anomalous where, as here, it is easy to establish a prima facie case. The government, after all, can carry its initial burden of production simply by presenting market concentration statistics. To allow the govemment virtually to rest its case at that point, leaving the defendant to prove the core of the dispute, would grossly inflate the role of statistics in actions brought under section 7. The Herfindahl-Hirschman Index cannot guarantee litigation victories.

908 F.2d 981,992 (D.C. Cir. 1990) (citation omitted).

22 Unlike other areas of antitrust law, the great majority of merger challenges are brought by government enforcement agencies: the FTC, the Antitrust Division of the U.S. Department of Justice and the state attorneys general. Standing requirements and the lack of damages explain the paucity of private challenges. For a notable recent exception in which a private medical clinic challenged a hospital merger after the FTC entered into a limited consent decree with the parties, see Santa Cruz Medical Clinic v. Dominican Santa Cruz Hospital, No. C93 20613 RMW, 1994 WL 619288 (N.D. Cal. Oct. 26, 1994) (finding plaintiff did have standing to sue).

23 See Response of the United States to Defendants' Proposed Findings of Facts and Conclusions of Law at 57, United States v. Rockford Mem'l Corp., 717 F. Supp. 1251 (N.D. Ill. 1989) (No. 88-C-20186) (stating that "a merger that reduces the number of competitors from three to two . . with a market share of over 70 percent in a market where entry is unlikely violates Section 1").

24 See Hospital Corp. of Am. v. Federal Trade Comm'n, 807 F.2d 1381, 1385-89 (7th Cir. 1986), aff'g 106 F.T.C. 361 (1985).

25 U.S. Dep'T OF JUSTICE \& Federal TRADE COMM'N, MERger Guidelines-1992, reprinted in 4 Trade Reg. Rep. (CCH) I 13,104, at 20,569 (Apr. 17, 1997) [hereinafter MERGER GUIDELINES].

26 Although the Guidelines contain the caveat that they do not attempt to assign or adjust the burden of proof or going forward with evidence, see MERGER GUIDELINES, supra note $25, \S 0.1$ (May 5, 1992), they proceed to discuss in detail the presumptive consequences of certain levels of concentration and market share. See id. $\$ \S 1.5,1.51$ (Apr. 7, 1992); see also infra note 27 (discussing horizontal mergers). Moreover, despite disclaimers that the Guidelines do not affect the position that the agencies will take in court, it is widely recognized that they are intended to influence the direction of merger jurisprudence in the federal courts and that they are likely to shape future litigation strategy. See MERGER GUIDELINES, supra note 25, $\S 0.1$ (May 5, 1992); see also AREEDA \& HOVENKAMP, supra note 11, I 905 'h, at 752 (discussing the government's approach to merger analysis).

27 Using the Herfindahl-Hirschman Index (HHI) as a measure of pre- and post-merger concentration levels, the Guidelines attach only modest consequences to high concentration levels and large increases in the HHI index. See MERGER GUIDELINES, supra note 25, $\S 1.51$ (c) (Apr. 7, 1992) (stating that post-merger increases that exceed 100 points in "highly concentrated markets" are presumed to create or enhance market power or facilitate its exercise; but the presumption "may be 
Guidelines discuss in considerable detail the various economic factors that support or refute the likelihood that the merged entity will "create or enhance market power or facilitate its exercise."28 The Guidelines enumerate a long list of circumstances that facilitate tacit or express collusion, such as product homogeneity, buyer characteristics, the number and size of sales, the presence of coordination-facilitating devices and historical pricing performance. 29 The Guidelines also list factors that facilitate single firm anticompetitive behavior, such as the closeness of the products of the merging firms $\mathrm{s}^{30}$ and capacity constraints ${ }^{31}$ and factors that generally affect the likelihood that the merged parties would be able to exercise market power, such as entry conditions $\mathrm{s}^{32}$ and changing technological conditions. ${ }^{33}$

The changes described above have caused a subtle but profound shift in the inquiries undertaken by courts in examining antitrust merger challenges. Prior case law had presumed that tacit or express collusion was a significant threat when market share and concentration data was high. ${ }^{34}$ By contrast, trial courts now routinely undertake detailed inquiries into the likelihood and effectiveness of post-merger collusion. ${ }^{35}$ Parties tend to present essentially a narrative to explain how collusion may or may not occur and how impediments to reaching agreements and policing agreements may affect the likelihood and success of cartelization schemes or oligopolistic pricing. ${ }^{36}$ Although an undeniably sound economic basis for considering the variety of factors discussed above exists, the results of these inquiries has not been altogether satisfactory. As the leading treatise on antitrust law points out, courts are "ill equipped to assess the relevance of each of these factors, assign weights to them, and then balance them against one another." 37 Moreover, given the continuing vitality of the underlying economic assumptions supporting the presumptive approach, there is good reason to attach a strong presumption that collusive activity will occur when high market-share and concentration statistics exist. ${ }^{38}$

overcome by a showing that the [other, nonstatistical market] factors make it unlikely" that such effects will occur); see also id. \$1.51(b) (stating that post-merger increases of more than 100 points in "moderately concentrated markets ... potentially raise significant competitive concerns depending on [other, nonstatistical market] factors").

28 See id. $\$ 1.51(\mathrm{c})$.

29 See id. \$2.1.

30 See id. \$ 2.211 .

31 See id. $\$ 2.22$.

32 See id. $\$ \$ 3.0-4$

33 See id. \$1.521.

34 See, e.g., United States v. Philadelphia National Bank which holds that a merger which produces a firm controlling an undue percentage share of the relevant market, and results in a significant increase in the concentration of firms in that market, is so inherently likely to lessen competition substantially that it must be enjoined in the absence of evidence clearly showing that the merger is not likely to have such anticompetitive effects.

374 U.S. 321,363 (1963).

35 See Robert H. Lande \& James Langenfeld, From Surrogates to Stories: The Evolution of Federal Merger Policy, ANTITRUST, Spring 1997, at 5, 6 (noting that "enforcers ultimately care about [a] firm's ability to raise price after a merger").

36 See Paul T. Denis, An Insider's Look at the New Horizontal Merger Guidelines, ANTITRust, Summer 1992, at 6, 6; Lande \& Langenfeld, supra note 35, at 6-7.

37 AREEDA \& HOVENKAMP, supra note 11,9905 ' $h$, at 752.

38 See id. (stating that "neither the stability and clarity of the underlying economic theory nor the ability of courts to manage that theory has improved sufficiently to warrant a departure from [the presumptive approach]"). 
Perhaps motivated by their inability to present convincing stories of collusive anticompetitive effects in markets involving differentiated products, antitrust enforcement agencies have recently shifted enforcement emphasis by stressing the adverse unilateral effects of such mergers. ${ }^{39}$ Under this analysis, proof that a merger will enable the merged entity to increase prices after the merger without cooperating with rivals will obviate the need to tell a speculative story about the likelihood of oligopolistic coordination or perhaps even to define a market. Although apparently used extensively by the agencies in merger investigations, ${ }^{40}$ the economic techniques and doctrinal implications have yet to be tested in litigation. It thus remains to be seen whether courts will dispense with the traditional requirement that the government define markets and prove market power as part of its prima facie case or accept sophisticated econometric evidence quantifying unilateral effects as sufficient proof to establish the government's case.

\section{Market Definition}

The analytic approach contained in the Merger Guidelines has also significantly affected market definition. Fact finders need to identify sellers that provide alternative sources for the merging parties' products. ${ }^{41}$ This entails delineating the relevant product and geographic markets affected by the merger. ${ }^{42}$ To do so the case law mandates an inquiry into the substitution responses of consumers: in product markets, the substitution of one product for another, ${ }^{43}$ and in geographic markets, the substitution of one seller for another. ${ }^{44}$ Under the methodology of the Merger Guidelines, adopted by most federal courts in recent years, the agency determines the substitutability of products or sellers by assessing the post-merger reaction of customers to a "small but significant and nontransitory increase in price." 45 Those products and services sold by the merging parties, together with any other products and services to which customers would turn in response to the hypothesized price increase, comprise the relevant product market. ${ }^{46}$ Likewise, the relevant geographic market consists of those sellers to whom customers would turn in response to the price increase. 47

Several important caveats must be noted about the Guidelines methodology for market definition. First, it is (or should be) regarded as more of an expression of fundamental economic principles than as a test that courts can readily apply in liti-

39 See Jonathan B. Baker, Unilateral Competitive Effects Theories in Merger Analysis, ANTITRUST, Spring 1997, at 21, 21; Carl Shapiro, Mergers with Differentiated Products, ANTITRUST, Spring 1996, at 23, 23-24.

40 See Baker, supra note 39 , at 21 (noting that "[u]nilateral theories are now by far the most common in the internal analyses of the antitrust agencies").

41 See MERGER GUIDELINES, supra note 25, § 2.0 (Apr. 7, 1992).

42 See id.

43 See United States v. E.1. du Pont de Nemours \& Co., 351 U.S. 377, 394-96 (1956) (noting that "commodities reasonably interchangeable by consumers for the same purposes" constitute the relevant product market); Twin City Sportservice, Inc. v. Charles O. Finley \& Co. 512 F.2d 1264, 1271 (9th Cir. 1975) (discussing the high cross-elasticity of demand for similar products), cert. denied, 459 U.S. 1009 (1982).

44 See generally Kenneth G. Elzinga \& Thomas F. Hogarty, The Problem of Geographic Markets in Antimerger Suits, 18 ANTITRUST BULL. 45, 45 (1973) (discussing geographic market definition).

45 Merger Guidelines, supra note $25, \S \S 1.11,1.21$ (Apr. 7, 1992).

46 See id. $\$ 1.11$.

47 See id. \$1.21. 
gation. 48 Although parties often offer responses to hypothetical questions as evidence on these issues, the speculative and contingent nature of such inquiries makes them of questionable probative value. ${ }^{49}$ Thus the Guidelines themselves appear to recognize that inferences drawn from concrete evidence or historical behavior patterns may provide more reliable indicia of the contours of the relevant market. ${ }^{50}$ Second, it is widely recognized that to delineate a market properly, the Guidelines test must observe whether customers would switch purchasing patterns if the sellers moved from a competitive price to a supracompetitive price. ${ }^{\text {I1 }}$ If prices in the alleged market are already significantly above competitive levels, the Guidelines standard does not identify an economically meaningful market because such markets will necessarily have a propensity for substitution if prices are raised further. Under the socalled "Cellophane fallacy," an overly broad market is identified when the starting point of the alleged market is an already monopolized price. 52 The Guidelines appear to recognize this difficulty, as they note that the agencies will base their analysis on "a price more reflective of the competitive price" where the evidence suggests that supracompetitive pricing is already occurring. 53 Nevertheless, these considerations confront the trier of fact with enormous difficulties. Before evaluating proof of price responsiveness, she must first determine whether current market prices are competitive. ${ }^{54}$ If not, she must determine whether proffered evidence is probative of the likelihood that consumers would switch in the event of an increase from a hypothetical, current, competitive price to a hypothetical, noncompetitive price. 55

\section{B. APPL YING THE Clayton ACt TO HOSPITAL MERGERS}

The case law and pronouncements by the federal enforcement agencies make it clear that, with a few minor exceptions, conventional antitrust law principles apply to hospital mergers. The joint Statements of Antitrust Enforcement Policy in Health

48 See 1 Barry R. FURROW et AL., Health LAW § 10-55, at 738 (1995) (stating "the concept of a market is probably best understood as an expression of the essential principals [sic] that must guide factual determinations rather than a precise analytic tool").

49 2A Phillip E. Areeda et al., ANTITrust Law I 538b, at 205 (1995) (noting that subjective testimony by customers that they would or would not defect in response to a price increase is unreliable).

50 See Merger GuIDELINES, supra note 25, $\$ 1.11,1.21$ (Apr. 7, 1992) (identifying as relevant evidence responses to past price increases, the timing and costs of switching and proof that sellers base business decisions on the prospect of buyer substitution).

5I See E. Thomas Sullivan \& Herbert hovenkamp, antitrust law, Policy and Procedure 818 (3d ed. 1994); Gene C. Schaerr, Note, The Cellophane Fallacy and the Justice Department's Guidelines for Horizontal Mergers, 94 YALE L.J. 670, 675 (1985).

52 See Schaerr, supra note 51, at 676.

53 See MERGER GUIDELINES, supra note 25 , 1.11 (Apr. 7, 1992). This reflects a policy change from earlier versions of the Merger Guidelines which had adopted a standard based on prevailing prices apparently on the grounds that the Clayton Act was designed to prohibit only those mergers that enhanced market power. See SUlLIVAN \& HovenKaMP, supra note 51, at 818; William F. Baxter, Responding to the Reaction: The Draftsman's View, 71 CAL. L. REV. 618, 620, 622 (1983).

54 The Merger Guidelines cope with the problem by adopting a presumption that pre-merger prices are competitive. They provide that the enforcement agencies will use prevailing prices to perform the test "unless circumstances are strongly suggestive of coordinated interaction, in which case the Agency will use a price more reflective of the competitive price." MERGER GUIDELINES, supra note 25, \$1.11 (Apr. 7, 1992).

\$s See id. 
Care 56 state that hospital acquisitions will be analyzed under the principles contained in the Merger Guidelines, except for a safe harbor allowing acquisitions of small hospitals with significant excess capacity. ${ }^{37}$ By contrast, several states have undertaken a decidedly more regulatory approach to hospital mergers. Some states have adopted antitrust immunity statutes that establish mechanisms for administrative approvals based on a variety of competitive and public policy factors. 58 In addition, a number of state attorneys general have entered into consent decrees under the Clayton Act that allow hospital mergers to proceed on the condition that the merged entity contribute some portion of all prospective cost savings attributable to the merger to charities, public health programs or other funds selected by the state. 59

Although these developments may indicate a degree of unease about restricting the ability of hospitals to consolidate in the rapidly changing health care environment, there is no indication that federal enforcement authorities are considering officially altering the legal benchmarks they apply in reviewing mergers. ${ }^{60}$ In practice, however, the federal authorities may not be treating hospital mergers like any other industry. According to some commentators, the agencies routinely exercise their prosecutorial discretion not to challenge many acquisitions that appear to violate the Merger Guidelines. ${ }^{61}$ Although the government has challenged relatively few hospi-

56 The statements were originally issued in 1993, see U.S. DEP'T OF JUSTICE \& FEDERAL TRADE COMm'N, Statements of ANTITRUST ENFORCEMENT POLICY IN THE Health CARE AREA, reprinted in 4 Trade Reg. Rep. (CCH) 13,151 , at 20,755 (Sept. 5, 1993), and were revised and expanded in September 1994. See U.S. DeP'T of Justice \& Federal Trade Comm'n, STATEMENTS of AN.

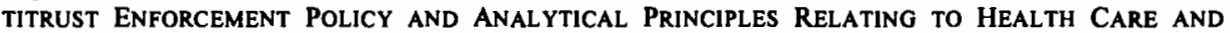
ANTITRUST, reprinted in 4 Trade Reg. Rep. (CCH) I 13,152, at 20,769 (Sept. 30, 1994) [hereinafter ENFORCEMENT POLICY].

57 See ENFORCEMENT POLICY, supra note 56, at 20,774 (setting forth nine statements regarding, inter alia, mergers, joint ventures, joint purchasing agreements, and multiprovider networks). The guidelines state that "[t]he Agencies will not challenge any merger between two general acute-care hospitals where one of the hospitals (1) has an average of fewer than 100 licensed beds ... and (2) an average daily inpatient census of fewer than 40 patients... [unless] that hospital is less than 5 years old." Id.

58 See, e.g., MinN. STAT. ANN. \$62J.2911-2921 (West 1996); N.D. CENT. CoDE $\$ 23-17.5-11$ (1993). See generally James F. Blumstein, Health Care Reform and Competing Visions of Medical Care: Antitrust and State Provider Cooperation Legislation, 79 CORNELL L. REV. 1459, 1486 (1994) (describing immunity statutes designed to facilitate cooperation among hospitals and other health care providers); Tina E. Kondo, State Enforcement Views, in ANTITRUST AND Health CarE: New APPROACHES AND Challenges 1, 1-8 (Health Law Section \& Section of Antitrust Law, American Bar Ass'n Oct. 1996) (summarizing the regulatory orders of certain states which grant state approval for health care transactions).

59 See, e.g., Pennsylvania v. Capital Heaith Sys. Servs., No. CIV.A.4:CV-95-2096, 1995 WL 787534, at 2 (M.D. Pa. Dec. 15, 1995) (ordering the merged entity to pass on at least $80 \%$ of the net cost savings to consumers "in the form of low-cost or no-cost health-care programs for the community or by reducing prices or limiting actual price increases for existing services"). See generally Thomas L. Greaney, Regulating for Efficiency in Health Care Through the Antitrust Laws, 1995 UTAH L. REV. 465, 486-89 (discussing how administrative agencies "have subtly shifted the locus of much decision-making authority in federal antitrust matters to themselves and away from the federal courts").

60 See William J. Baer, Current Issues in Health Care Antitrust Enforcement at the Federa Trade Comm'n, Address Before the American Bar Association (Oct. 24, 1996), available in 1996 WL 613763 (address given as Director, Bureau of Competition, Federal Trade Commission).

61 See Joe Sims, A New Approach to the Analysis of Hospital Mergers, 64 ANTITRUST L.J. 633, 635 (1996). 
tal mergers, ${ }^{62}$ the extent to which the agencies sidestep potential merger cases involving the hospital industry more readily than they do in other industries has not been empirically demonstrated. It is at least possible that the failure to challenge certain mergers is attributable to the uncertainties associated with resolving many fact-intensive issues in hospital markets.

Although, as discussed below in Part III, significant controversies still surround the application of antitrust law to hospital mergers, a rough consensus has emerged on several important issues. First, the cases identify the relevant product market as the cluster of services consisting of "general acute care hospital services," i.e., those services offered by hospitals for which there are no outpatient substitutes. ${ }^{63}$ Courts emphasize that the existence of outpatient alternatives for some hospital procedures does not place any check on pricing those procedures that cannot be performed on an outpatient basis. 64 Although that core may be shrinking as more and more services once provided only on an inpatient basis are performed in doctors' offices or in other facilities on an outpatient basis, there has been almost universal acceptance of the inpatient market as a distinct relevant market in applying the Clayton Act.65 Second, the geographic market has been treated as primarily local, owing to the emergency nature of some care, the preference of people to be hospitalized near their families and homes, physician staff privileges and other factors. 66 Notably, this analysis tends to narrow somewhat the core product market, as courts tend to focus only on the acute care inpatient services that do not entail extremely sophisticated tertiary care.67 Third, courts have applied the rule of presumptive illegality and then pro-

62 Between 1987 and 1991, the FTC and DOJ investigated only 27 out of some 229 hospital mergers; only five of those investigations resulted in challenges. See 1 ANTITRUST SECTION,

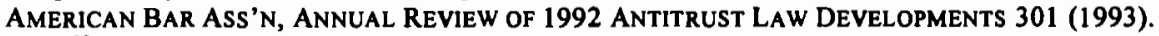

63 See, e.g., United States v. Rockford Mem'l Corp., 898 F.2d. 1278, 1284 (7th Cir. 1990) (reviewing a market that consisted of inpatient acute care services). In the recent cases, the parties stipulated that the relevant product market was inpatient general acute care services. See, e.g., United States v. Mercy Health Servs., 902 F. Supp. 968, 976 (N.D. Iowa 1995); In re American Med. Int'l, 104 F.T.C. 1, 192-94 (1984). But see United States v. Carilion Health Sys., 707 F. Supp. 840, 847 (W.D. Va.) (stating that a relevant product market includes "not only other inpatient hospitals but also various outpatient clinics that treat medical problems for which patients might otherwise have sought treatment in an inpatient hospital setting"), aff'd, 892 F.2d 1041, 1042 (4th Cir. 1989) (unpublished opinion).

64 The point is summarized by Judge Posner:

If you need a kidney transplant, or a mastectomy, or if you have a stroke or a heart attack or a gunshot wound, you will go (or be taken) to an acute-care hospital for inpatient treatment. The fact that for other services you have a choice between inpatient care at such a hospital and outpatient care elsewhere places no check on the prices of the services we have listed, for their prices are not linked to the prices of services that are not substitutes or complements. Rockford, 898 F.2d at 1284.

65 See 2 MiLES, supra note $4, \S 12: 9$, at 12-27 (noting that "courts and the Federal Trade Commission thus far (except Carilion) have defined the relevant product market simply as inpatient services provided by short-term general acute care hospitals"); see also infra Part III.C (discussing Federal Trade Comm'n v. Butterworth Health Corp., 946 F. Supp. 1285 (W.D. Mich. 1996), which recognized that general acute care inpatient hospital services and primary care inpatient services are both relevant product markets).

66 See, e.g., United States v. Rockford Mem'l Corp., 717 F. Supp. 1251, 1261-78 (N.D. Ill. 1989) (describing geographic markets). But see Mercy Health, 902 F. Supp. at 986 (criticizing Rockford's assumptions).

67 See Federal Trade Comm'n v. Freeman Hosp., 69 F.3d 260, 268 (8th Cir. 1995) (noting failure of the government to prove that patient flow to distant hospitals was to obtain sophisticated care or services unavailable in local facilities); Rockford, 717 F. Supp. at 1277 (discounting importance 
ceeded to consider a broad range of factors that may support or undermine inferences to be drawn from market concentration and market-share evidence. ${ }^{68}$ These factors have included the not-for-profit status of hospitals in the market, the presence of sophisticated buyers, excess capacity, entry restrictions and the heterogeneity of service offerings. 69 Finally, most courts have undertaken an evaluation of proposed efficiencies attributable to the merger, ${ }^{70}$ although significant differences exist in the way they assign proof burdens and otherwise weigh the significance of purported cost savings. ${ }^{71}$

\section{SHIFTING SEAS: FACTORS COMPLICATING ANALYSIS OF HOSPITAL MERGERS}

Many features peculiar to hospital mergers complicate antitrust analysis.72 Taken together with the uncertainties introduced by the current drift of antitrust doctrine, these problems could produce an unpredictable, standardless jurisprudence.

\section{A. Changing Market Conditions}

The upheaval occurring in health care markets muddles judicial fact finding and application of merger doctrine to hospital consolidations. Managed care and changing governmental policies affect virtually every aspect of the health care industry. Buyer insistence on competitive pricing has led hospitals to undertake enormous changes in search of cost containment and greater bargaining leverage for the future. $^{73}$ As hospitals reorganize, consolidate and integrate in order to negotiate better with managed care entities, the fundamentals of their business operations are changing rapidly. Markets shift as hospitals seek out new sources of admissions and seek to encourage new sources of referrals; cost containment efforts cause significant al-

of flow of tertiary referral patients in constraining exercise of market power because many travel for services not offered by local hospitals).

68 See Mercy Health, 902 F. Supp. at 976 (citing United States v. Citizens \& S. Int'l Bank, 422 U.S. 86, 120-21 (1975)).

69 See Rockford, 898 F. Supp. at 1278-91 (looking at factors such as concentration, barriers to entry and the nature of competition and market participants in order to determine whether practices are likely to be anticompetitive).

70 See, e.g., Mercy Health, 902 F. Supp. at 987.

71 See, e.g., Rockford, 898 F.2d at 1285 (finding defendant's efficiencies evidence incomplete and questioning whether the claimed efficiencies were solely due to the merger, and requiring clear and convincing evidence showing that the benefits of the efficiencies outweighed the anticompetitive effects of the merger); Mercy Health, 902 F. Supp. at 976 (holding that if the defendant is successful in rebutting the government's statistical evidence, the government then has the burden of presenting additional evidence that the merger will lessen competition).

72 See, e.g., Jonathan Choslovsky, Agency Review of Health Care Industry Mergers: Proper Procedure or Unnecessary Burden?, 10 ADMIN. L.J. AM. U. 291, 305-09, 319-24 (1996) (recommending procedural reforms to clarify standards and reduce uncertainty, and responding to criticisms that health care antitrust decisions are inconsistent).

${ }^{73}$ See Mary Chris Jaklevic, Survey: PHOs a Popular Managed Care Strategy, MoD. HeAlTHCARE, Feb. 5, 1996, at 33, 33 (reporting that $71 \%$ of hospitals sponsored physician-hospital organizations); Lisa Scott, Purchasing Groups Add to Their Bulk, MoD. HeAlTHCARE, Sept. 23, 1996, at 54, 54 (reporting that the 10 largest group purchasing organizations accounted for $60 \%$ of all supply purchases by nonfederal hospitals in 1995); Lisa Scott, Will We Like Tomorrow's Giants?, Mod. HealthCARE, Aug. 5, 1996, at 79, 79-80 (citing estimates that 2.4 mergers and acquisitions occurred per day among all types of providers in the first half of 1996 , one hospital merger occurred every three days in the past 2.5 years and one-fifth of all community hospitals changed ownership in 1994-1995). 
terations in where and how services are delivered; and prices fluctuate as buyers insist on favored treatment in exchange for more referrals. ${ }^{74}$ Defining today's markets, much less predicting their dimensions over the next few years, is thus, at best, an educated guess. Relative concepts like improved efficiency lose their meaning and economic standards such as minimum efficient scale become elusive in such a rapidly changing delivery environment.

\section{B. CLUSTER MARKET CONFUSION}

The cluster market concept discussed above is an economically sound method of aggregating the goods or services of multi-product firms where complementarities in production and consumption of goods or services make the costs of jointly producing those goods lower than individually producing and consuming the cluster's components. ${ }^{75}$ In the hospital context, the application presents problems for purposes of economic analysis because many of the services included in the cluster are not substitutes or complements and they might not be demanded by buyers as a package. ${ }^{76}$ Use of a cluster market can be justified on pragmatic grounds when all the elements of the cluster are commonly sold by sellers, or when purchasers buy the cluster as a package for convenience or transaction cost savings. ${ }^{77}$ However, given that managed care purchasers may buy less than the full complement of acute care inpatient services from some hospitals (for example, choosing to purchase certain tertiary care services from only one hospital), or that the elements of the cluster may have decidedly different characteristics, the cluster approach may misrepresent market conditions. 78

Confusion with respect to defining geographic markets, however, presents perhaps the greatest problem with the cluster market approach. As discussed below, because of data limitations, courts often fail to distinguish patient flow statistics based on what services persons traveling unusual distances received. ${ }^{79}$ Where individuals receive care from distant hospitals because of emergencies or the failure of

74 See Carl H. Hitchner et al., Integrated Delivery Systems: A Survey of Organizational Models, 29 WAKE FOREST L. REV. 273, 273-74, 279 (1994).

75 See Ian Ayres, Rationalizing Antitrust Cluster Markets, 95 YALE L.J. 109, 114-15 (1985); Michael E. Vita et al., Economic Analysis in Health Care Antitrust, 7 J. CONTEMP. HEALTH L. \& POL'Y 73, 80-85 (1991).

76 For example, from the patient's perspective, inpatient obstetrical services are not substitutes for chemotherapy services. Nor are they complements in the sense that offering one service makes provision of the other less costly. Whether the joint provision of the two services affords transaction cost savings in managed care contracting will depend on the costs in carving out certain services from the package that the buyer negotiates with hospitals.

77 See Jonathan B. Baker, The Antitrust Analysis of Hospital Mergers and the Transformation of the Hospital Industry, 51 LAw \& CONTEMP. ProBs. 93, 126 (1988) (arguing that if there is no compelling reason to believe that demand and supply substitutability opportunities, entry conditions or market shares differ significantly across individual products, then the antitrust analysis will be similar for each good so they may conveniently be analyzed as a collection).

78 To depict economically meaningful markets accurately it is necessary to fine tune the cluster, which includes only services that are purchased by buyers in a package because of complementarities or transaction cost savings. See $i d$. at 126,128 . The trend in litigation has been to narrow the cluster, with the antitrust enforcement agencies eliminating tertiary care services, see United States v. Mercy Health Servs., 902 F. Supp. 968, 981-83 (N.D. lowa 1995), or reducing the entire package to primary care services. See Federal Trade Comm'n v. Butterworth Health Corp., 946 F. Supp. I285, 1291 (W.D. Mich. 1996).

79 See infra Part IV (discussing these limitations of data in the context of three specific court opinions). 
their local hospitals to offer those services, those motivations need to be taken into account before mechanically applying tests based on the numbers of patients traveling into or out of a provisional market.

\section{DIFFERENTIATED PRODUCTS}

Among the most important factors affecting the dynamics of hospital competition is the fact that hospitals sell highly differentiated products. Consumers make critical distinctions among hospitals based on quality, reputation, geographic location, amenities and other factors. The economic literature 80 and the Merger Guidelines ${ }^{81}$ have long recognized that in such circumstances mergers between firms that are close substitutes pose the risk that the merged entity will be able to raise price unilaterally even though market-wide collusion is unlikely. Thus, in hospital merger cases where a significant portion of the patients of one merging hospital view the other as its second choice, it may be profitable for the merged hospitals to raise price regardless of whether other hospitals in the market go along. ${ }^{82}$

Although the agencies have only recently begun applying this theory in merger investigations and no cases have as yet been litigated based primarily on this mode of analysis, it may have profound implications for antitrust merger jurisprudence. Both the nature of proof required and the kinds of mergers challenged may be affected. In its broadest application, unilateral effects analysis may enable courts to dispense entirely with market definition; proof of effect should, as a matter of logic, obviate the need to establish markets. Moreover, it may be used to strike down mergers involving firms with very low market shares. ${ }^{83}$ At a minimum, the approach may be used in merger cases to refocus the inquiry to examine the effects of mergers on specific groups of customers and perhaps to adjust inferences of likely effect based on market share and concentration data.84 Finally, appreciation of differentiation among hospitals may affect courts' analyses of geographic markets. The fact that some patients travel considerable distances to obtain services may be a product of differences among individuals in their perceptions of alternative hospitals; the

80 See, e.g., Baker, supra note 39 (reviewing the unilateral theories of the adverse competitive effects of mergers and detailing an example); Shapiro, supra note 39 (discussing various supplemental methods used by the Antitrust Division of the DOJ to analyze unilateral effects in mergers involving differentiated products); Gregory J. Werden \& Luke Froeb, The Effects of Mergers in Differentiated Products Industries: Logit Demand and Merger Policy, 10 J.L. ECON. \& ORG. 407 (1994) (examining the effects of mergers under a logit demand system model).

81 The 1982 Merger Guidelines stated that the Department of Justice was "more likely to challenge" mergers where the products of the merging firms were "particularly good substitutes for one another." See U.S. DEP'T OF JUSTICE, MERGER GUIDELINES-1982, reprinted in 4 Trade Reg. Rep. (CCH) ๆ 13,102, at 20,538 (Apr. 23, 1997). In their current iteration, the Merger Guidelines explicate in considerable detail the circumstances in which the enforcement agencies may apply unilateral effects theories to challenge a merger. See MERGER GuIDELINES, supra note $25, \S 2.2$ (Apr. 7, 1992).

82 A number of conditions must be met however: the likelihood of the effect depends on, for example, whether other hospitals in the market can reposition themselves and the nature of consumers' demand for hospitals' services. See Baker, supra note 39, at 21-22 (discussing necessary conditions in the context of an auction model merger hypothetical); see also Shapiro, supra note 39, at 23.

83 See Lande \& Langenfeld, supra note 35 , at 7.

84 See id. at 6; see also MERGER GUIDELINES, supra note 25, $\$ 2.21$ (Apr. 7, 1992) (discussing unilateral effects in price resulting from mergers between firms distinguished primarily by differentiated products). 
convenience of one facility given the locations of their homes, workplaces or relatives or other factors. Hence, generalizations based on patient flow statistics are subject to numerous qualifications.

\section{AgENCY and Transaction Costs In the PuRchase of Health InSURANCE}

The overwhelming majority of Americans purchase health insurance through their employers and today nearly three-fourths of them have chosen plans that rely on managed care arrangements with providers. ${ }^{85}$ The employer negotiates in the first instance with insurers or health plans and typically pays a substantial portion of the premium. ${ }^{86}$ Employees then choose from the plans selected by the employer. For most employees, the choice is limited to a small number of plans; most small employers offer only one plan.87 Employers, especially those with relatively few employees, face high transaction costs in administering health plan coverage 88 and consequently tend to contract with fewer plans than their larger counterparts.89 Thus to some extent, the employer acts as agent for its employees in purchasing health insurance. As such, it seeks to choose plans that afford the mix of quality, price and geographic coverage that best suits most of its employees. At the same time, the employer is an imperfect agent because it cannot know the preferences of all its employees. Further, because it pays the lion's share of the insurance premium but does not suffer directly the consequences of shortfalls in quality its interests are not perfectly aligned with those of its employees.

The implications of the foregoing analysis for evaluating hospital mergers are several. Employers must choose a plan or plans that accommodate the needs of their employees while still obtaining the benefits of selective provider contracting which many plans offer. Hence, employers are well equipped to evaluate and testify about the decisions and trade-offs involved in selecting a plan that offers access to hospitals. Further, the preferences of individual employees cannot be decisive, as employers attempt to balance competing interests; consequently, employers must choose plan(s) that suit most employees but they obviously cannot accommodate the first choices of all. Another consequence that flows from the fact that employers represent groups of subscribers is that providers and insurers may be able to price discriminate against certain employers or exercise market power as a result of the market imperfections inherent in the agency relationship.

\section{E. NATURAL MONOPOLY}

The fact that some hospital services are natural monopolies confounds the problems of defining markets and evaluating and dealing with market power. For such services, a single firm will produce the service for the entire market at lower

85 See Gail A. Jensen et al., The New Dominance of Managed Care: Insurance Trends in the 1990s, HEALTH AFF., Jan./Feb. 1997, at 125, 126.

86 See $i d$. at 131 (stating that employers contributed on average $86 \%$ of the health insurance premium for employees with single coverage and over $66 \%$ of the premium for those with family coverage).

87 See id. at 127 (stating that $62 \%$ of all workers offered two or more plans).

88 See Michael A. Morrissey et al., Small Employers and the Health Insurance Market, HEALTH AFF., Winter 1994, at 149, 153.

89 See $i d$. at 152 (reporting that only two percent of small business employers offer more than one health insurance plan to its employees). 
costs than could multiple competing firms. 90 Economies of scale, usually associated with large fixed costs, are the most common cause of natural monopolies in singleproduct markets.91 However, in the case of multi-product firms, such as hospitals, economies of scope and joint production may also contribute to natural monopoly when several services are offered jointly. 92

Considerable unresolved dispute exists in the economics literature over the extent to which entire hospital markets are natural monopolies. ${ }^{93}$ Nevertheless, the presence of some natural monopolies among the products or services in the cluster of acute care services creates a problem for antitrust enforcement. From an economic and policy perspective, natural monopolies should be treated quite differently than other monopolies. ${ }^{94}$ That is, rather than increasing the number of competitors, consumers are better off when natural monopolies are allowed to serve the entire market.

\section{F. Regulation AND Government Payment Policies}

Federal and state governments pay a large percentage of the total inpatient charges of acute care hospitals.95 That governmental payors can, to some extent, dictate the price they will pay may affect the analysis of market power and competitive circumstances. For example, hospitals heavily dependent on low-paying government programs may have stronger incentives to collude or exercise market power $v i s$-à-vis private payors than other hospitals. Or, governmental payors may have policies favoring certain hospitals, e.g., preferences that local community hospitals secure managed care contracts. Such policies may facilitate the unilateral exercise of market power. Conversely, when government reimbursement programs are relatively generous, the calculus of the marginal benefits and risks of collusion may make the exercise of market power less appealing for hospitals providing a large proportion of care to beneficiaries of such programs. In any event, predicting the course of future government regulation of hospital markets is itself fraught with uncertainty. Some government programs such as Medicaid are changing from priceregulated payment methodologies to market-based methods while the future of market-based Medicare reform remains uncertain. However, some states have adopted regulatory mechanisms that encourage consolidations and seek to regulate price directly or indirectly through these means. 96

\section{CRASH LANDINGS: RECENT HOSPITAL MERGER DECISIONS}

This section discusses three recent hospital merger decisions that illustrate the muddle produced by the current state of antitrust merger law as it applies to the health care sector.

90 See Dayna B. Matthew, Doing What Comes Naturally: Antitrust Law and Hospital Mergers, 31 Hous. L. REV. 813, $831-44$ (1994).

91 See id. at 826-27.

92 See id. at 827.

93 See id. at 837-52 (summarizing studies which suggest an inverse relationship between hospital cost and concentration, but also noting that other studies suggest that this inverse relationship might not be due to a lack of competition).

94 See id. at 854-72 (stating that unlike other monopolies, natural monopolies are believed to benefit consumers through increased efficiencies).

95 See id. at 848.

96 See sources cited supra note 58. 


\section{A. MERGER DECISIONS}

\section{Federal Trade Commission v. Freeman Hospital}

The FTC's rather tempestuous litigation challenging the merger of Freeman Hospital and Oak Hill Hospital in Joplin, Missouri, illustrates some of the potential difficulties in applying antitrust law to hospital mergers. ${ }^{97}$ The FTC staff sought a temporary restraining order and a preliminary injunction to stop the merger of these two hospitals.98 Unfortunately, the FTC found itself before a district court judge openly unsympathetic to federal antitrust enforcement. ${ }^{99}$ Additionally, the FTC was burdened with a set of facts that, at least in retrospect, seemed highly unappealing though well within the reach of the case law. 100 Prior to the merger, Joplin was a three-hospital town.101 The largest, St. John's Regional Medical Center, had 331 beds. 102 The two merging hospitals were significantly smaller: Freeman Hospital had 158 beds and Oak Hill operated 96.103 In addition, Oak Hill was an osteopathic hospital (a factor that limited its appeal in the marketplace), in poor financial condition, and with a relatively small base of private pay patients. 104 Weighing in favor of challenging the merger was the fact that there were three other bidders for Oak Hill and the trustees predicated their choice of Freeman on a variety of criteria that included favoring bidders with a stronger strategic position in the Missouri health care market. 105

The district court found that the FTC failed to meet its burden in establishing a geographic market.106 The court predicated its holding on its conclusion that the FTC's evidence relied on "where residents of the greater Joplin area actually went, as opposed to where they could practically go, for acute care inpatient hospital services."107 The court concluded that such evidence was insufficient because it ignored other geographically proximate hospitals to which patients could turn. ${ }^{108}$ The Eighth Circuit upheld the district court's denial of the preliminary injunction on this ground alone. 109

97 See Federal Trade Comm'n v. Freeman Hosp., 69 F.3d 260, 266-73 (8th Cir. 1995) (discussing the FTC's jurisdiction over nonprofit hospital mergers under the Clayton Act and the application of the appropriate standard of review to the merits of the instant case).

98 See id. at 263.

99 Judge Whipple initially denied preliminary relief to the FTC without holding an evidentiary hearing. See Federal Trade Comm'n v. Freeman Hosp., No. 95-5015-CV-SW-1, 1995 WL 228319, at 1 (W.D. Mo. Feb. 28, 1995). In so doing, the court mentioned in its opinion that "[i]t looks to me like Washington D.C. once again thinks they know better what's going on in southwest Missouri. 1 think they ought to stay in D.C." and told complaint counsel " 1 don't think you've got any business being in here." Freeman Hosp., 69 F.3d at 263 (quoting judge at temporary restraining order hearing). After remand from the court of appeals ordering an evidentiary hearing, the court conducted a two-day trial allowing each side to present only three witnesses. The court of appeals stated that it was "disturbed" about the "injudicious" remarks made by the district court judge but rejected the FTC's claim that they exhibited bias against the agency. See id. at 272-73.

100 See Freeman Hosp., 69 F.3d at 266-73.

101 See id. at 262.

102 See id.

103 See id.

104 See Freeman Hosp., 911 F. Supp. at 1224-25.

105 See Freeman Hosp., 69 F.3d at 263 n.4.

106 See Freeman Hosp., 911 F. Supp. at 1226-27.

107 Id. at 1227.

108 See id.

109 See Freeman Hosp., 69 F.3d at 272. 
The district court articulated a second basis for denying preliminary relief. It identified a series of factors that impact the likelihood of anticompetitive effects. 110 Specifically, as a nonprofit hospital supported by the local community with significant consumer representation on its board, the merged hospital would function more like a consumer cooperative than a profit-maximizing competitor, and thus would be unlikely to raise prices arbitrarily to earn higher profits. ${ }^{111}$ The court identified a second factor in its belief that the merged entity would compete more effectively against the dominant hospital, especially considering the declining position of Oak Hill Hospital. 112 In this regard, the court noted that Oak Hill suffered from perceived disadvantages in the marketplace owing to its being an osteopathic hospital.113 The court also considered the fact that only a small percentage of Oak Hill's patients were privately insured.114 Given that government health insurance programs (Medicare and Medicaid) pay set prices, the court concluded that the merger would have a less anticompetitive effect than one in which a significant share of private pay patients would be impacted. 115 Finally, the court noted that no third-party payors objected to the merger, a fact of significance to the court because "these payors will ultimately bear the brunt of any higher prices caused by the consolidation."116

The court undertook a checklist approach to analyze competitive effects. The court simply identified factors that seemed to lessen the significance of Oak Hill as a competitive factor or that seemed to diminish incentives of the merged entity to raise prices. The court relied on factors that include both broad-brush generalizations about economic behavior unsupported by hard evidence, 117 as well as factors that may improve the competitive strength of the merged entity but do not by themselves explain why collusive economic power will not be exercised.118

On the issue of geographic market, both the district court and the court of appeals faulted the FTC for not paying sufficient attention to the dynamic analysis of the market.119 The Eighth Circuit found no abuse of discretion in the district court's holding that the "FTC failed to produce sufficient evidence on the crucial aspect of the geographic market: where consumers of acute care inpatient hospital services could practicably turn for alternative sources of that product." 120 It is unclear from either opinion, however, whether the two courts were faulting the quantity or the

110 See id. at 263 n. 4.

111 See Freeman Hosp., 911 F. Supp. at 1222.

112 See id. at 1224.

113 See id. at 1225.

114 See id. at 1224-25.

115 See id. "Because reimbursement amounts for Medicare and Medicaid patients are dictated by the government, the exercise of monopoly power through higher prices has an adverse effect only on private-pay patients." Id. at 1224.

$116 \mathrm{Id}$. at 1223 .

117 See id. at 1223-24 (discussing the opinions of third-party payors who expressed no objection to the merger).

118 See id. at 1224-25 (discussing the competitive significance of the proportion of a hospital's private paying patients, the decline in a hospital's total inpatient admissions and the degree to which a seller in a particular market can underprice its rivals).

119 See Freeman Hosp., 69 F.3d at 271-72 (stating that the "FTC failed to meet its burden of establishing the relevant geographical market"); Freeman Hosp., 911 F. Supp. at 1220 (holding that "[i]nformal, off-the-cuff remarks and anecdotal evidence concerning the marketplace are no substitute for solid economic analysis").

120 Freeman Hosp., 69 F.3d at 269. 
quality of the Commission's proof. ${ }^{121}$ Moreover, both courts appear to have demanded a degree of certainty that seems highly questionable given the standard for preliminary injunctive relief. 122

First, the Eighth Circuit gave no credence to the proof of the geographic market established by patient flow data. ${ }^{123}$ It held instead that such data "provide[s] no insight into the future effects of the allegedly anti-competitive merger of the Hospitals."124 This unnecessarily restricts the value of historical patient migration.125 Although it is widely accepted that historical patterns do not by themselves suffice to prove a market, they can at least support the inference that a market exists. ${ }^{126}$ After all, historical patient migration patterns reflect consumer preferences over time and during a variety of market conditions. Assuming fluctuating prices and less-thanperfect market conditions existed in the hypothetical market, the absence of significant in- and out-migration does provide a certain degree of dynamic evidence. Hence patient-origin data is not necessarily as static as courts depict it.

More important, the FTC did introduce dynamic evidence.127 Specifically, the perceptions of market participants - competitors, buyers and consumers in the marketplace-supported the FTC's proposed market. ${ }^{128}$ As the court acknowledged, these individuals "testified that even if the Joplin health care prices increased after the merger due to collusion between the remaining Joplin hospitals, few patients currently traveling to Joplin for care would travel instead to hospitals located outside of FTC's proposed geographic market."129 Without identifying any rebuttal evidence

121 See id. at 269-72 (itemizing and discussing the insufficiencies of the FTC's expert testimony in support of the preliminary injunction); Freeman Hosp., 911 F. Supp. at 1226-27 (same).

122 See Freeman Hosp., 69 F.3d at 272-73; Freeman Hosp., 911 F. Supp. at 1227-28. To obtain a preliminary injunction under section 13(b) of the Federal Trade Commission Act, the FTC must raise "questions going to the merits so serious, substantial, difficult and doubtful as to make them fair ground for thorough investigation, study, deliberation and determination by the FTC in the first instance and ultimately by the Court of Appeals." Federal Trade Comm'n v. National Tea Co., 603 F.2d 694, 698 (8th Cir. 1979) (quoting Federal Trade Comm'n v. Beatrice Foods Co., 587 F.2d 1225, 1229 (D.C. Cir. 1978)). The Eighth Circuit rejected the FTC's argument that the National Tea standard applied to its burden with respect to proving a relevant geographic market. See Freeman Hosp., 69 F.3d at 268 n. 12.

123 See Freeman Hosp., 69 F.3d at 265. The district court adopted the alternative analysis of patient migration patterns offered by defendants' expert, Dr. Lynk. See id. at 266 . However, the Eighth Circuit accepted for purposes of appeal the FTC's patient flow proof, but found it insufficient to establish a geographic market. See id. at 269 (noting that despite Dr. Lynk's concerns that the analysis by the plaintiff's expert, Dr. Leffler, was incomplete and incorrect, his analysis failed to resolve the market definition issue).

124 Id. at 269.

125 See id.

126 See United States v. Rockford Mem'l Corp., 717 F. Supp. 1251, 1266-75 (N.D. Ill. 1989), aff'd, 898 F.2d 1278 (7th Cir. 1990); see also AREEDA ET AL., supra note 49, q 534a3, at 180 (stating that "antitrust authorities often have little choice but to rely on historical data of . . . trading patterns. They must always recognize, however, that the inferences to be drawn are, at best, presumptions that must give way when reliable adjustments are feasible to take account of their deficiencies."); Gregory J. Werden, The Limited Relevance of Patient Migration Data in Market Delineation for Hospital Merger Cases, $8 \mathrm{~J}$. HEALTH ECON. 363, 376 (1989) (concluding that the most important issue in determining the geographic scope of hospital markets is whether an attempt to exercise market power by raising prices would be thwarted by changes in patient migration). See generally Elzinga \& Hogarty, supra note 44 , at 45 (noting that market is commonly defined as a seller of a particular product, a buyer of a particular product or a particular place of exchange).

127 See Freeman Hosp., 69 F.3d at 269.

128 See id.

$129 \mathrm{Id}$. 
or other facts contradicting that testimony, the court nevertheless discounted its probative value:

[T] he views of market participants are not always sufficient to establish a relevant market, especially when their testimony fails to specifically address the practicable choices available to consumers. . . . The testimony from market participants ... spoke mainly to current competitor perceptions and current consumer habits and not to the crucial question of where consumers could practicably go . . . 130

The court thus confronted the FTC with an evidentiary burden worthy of Catch 22: hard evidence like historical patient-origin data was unacceptable because it did not address future contingencies, and managed care testimony was inadequate, although it addressed future contingencies, because it lacked the specificity of hard evidence.

The court's stated basis for dismissing the testimony of market participants reveals a standard of precision that seems totally inappropriate in such a hypothetical, future-oriented inquiry. The quoted passage may be read to imply that it was incumbent on the FTC's witnesses to identify specific practicable alternatives - that is, to name facilities - to which consumers would turn in the event of an exercise of market power by the merged hospital. Given the nature of the question at hand (how managed care organizations (MCOs) and their enrollees would respond to a hypothetical future increase, everything else held constant), requiring such specific proof is highly problematic. It requires the government to produce witnesses who can credibly identify by name those hospitals to which they would turn even though they have never had any experience with such an eventuality. Properly framed, however, the ultimate question on the issue of geographic market should be how far would consumers travel and to what kind of facility they would go given a strong economic incentive. The evidence offered by the FTC, and dismissed by the court, seemed to speak as directly and persuasively to that question as any testimonial evidence could.

An alternative reading of the court's analysis is that it required more concrete proof than the subjective testimony of buyers about where they might turn. Admittedly, such testimony is subject to important qualifications and reservations. ${ }^{131} \mathrm{Nev}-$ ertheless, it is not clear what kind of concrete proof would suffice given the nature of the inquiry. The principal objective evidence that might occasionally be available would be historical responses of customers and other hospitals. Certainly, the court could reasonably draw conclusions from such evidence, and leading commentators have emphasized that they should do so. 132 Unfortunately, such evidence generally will be unavailable. Moreover, to draw inferences from past shifts about future shifts, one must hold demand, supply and a variety of other factors constant. ${ }^{133}$ The rapidly changing market conditions in health care financing and delivery would seem to make this an impossible undertaking.

Even where the FTC offered historical evidence to buttress its case, the court found it insufficient. 134 The court discounted the testimony of administrators from hospitals located at the fringe of or outside the FTC's proposed market to explain the

$130 \mathrm{Id}$. at 270 (emphasis added).

131 See AREEDA ET AL., supra note 49, I 538b, at 205-06.

132 See id. Tf 538-538a, at 203-05.

133 See id. 9 538, at 203.

134 See Freeman Hosp., 69 F.3d at 269. 
circumstances motivating patient migration from their regions. ${ }^{135}$ Presumably such evidence would have added to the government's dynamic case by establishing that past migration was not in response to price differentials, thus allowing the fact finder to draw inferences about consumers' responses to price increases in the future. 136 The administrators testified that patients have historically traveled to Joplin mainly to obtain services not otherwise available in their local hospitals. 137 The Eighth Circuit discounted this testimony because of the absence of "significant economic or statistical data" supporting it. 138 By setting the bar so high even for uncontradicted evidence from expert hospital administrators, the court seemed to signal that the fact finder should grant no particular credence to historical evidènce over the hypothetical testimony discussed above.

\section{United States v. Mercy Health Services}

In United States v. Mercy Health Services, a district court refused to enjoin the proposed merger of the only two general acute care hospitals in Dubuque, Iowa. 139 Again, geographic market became the decisive issue. 140 The government's proposed geographic market included Dubuque County, Iowa, and a half-circle radius of fifteen miles extending from Dubuque County's eastern edge into Illinois and Wisconsin.141 Approximately eighty-six percent of all patients residing within this market used the merging hospitals. 142 In a startling result, the district court rejected the government's market definition, and accepted instead the defendant's contention that several regional hospitals located between 70 and 100 miles from Dubuque constituted an alternative that would constrain monopoly pricing by the merged entity. ${ }^{143}$ At the same time, it concluded that several small rural hospitals located within seventy miles of Dubuque would not provide a practical alternative to defeat the market power of the merging hospitals. ${ }^{144}$ The court's basis for its highly improbable ${ }^{145}$

135 See id. at 270 .

136 See id.

137 See id. The FTC advanced this testimony to establish that differences in quality and range of services differentiate Joplin hospitals from those in the markets identified by the defendants and tend to negate the assertions of the defendants' experts that such hospitals are competitors merely because of their geographic proximity to Joplin. See id.

138 See id. The court noted that "the FTC could have compiled and analyzed the DRG [diagnostic-related group] records of hospitals potentially in the geographic market to determine whether significant differences exist." Id. at 271.

139902 F. Supp. 968, 989 (N.D. Iowa 1995). While the appeal was pending, the hospitals announced that they had abandoned plans to merge. See United States v. Mercy Health Servs., 107 F.3d 632, 635 (8th Cir. 1997). Although both the government and the defendants argued that the appeal was not moot because the parties had not foresworn the possibility of merging or forming an alliance in the future, see id., the Eighth Circuit dismissed the appeal and vacated the district court's decision. See id. at 634.

140 See Mercy Health, 902 F. Supp. at 987.

141 See id. at 976.

142 See id.

143 See id. at 980 . Although several small rural hospitals competed within a closer radius, the court found those hospitals could not similarly constrain the behavior of the merged hospital. See id.

144 See id.

145 In United States v. Rockford Memorial Corp., Judge Posner derisively rejected defendants' proposed market:

[F]or the most part, hospital services are local. People want to be hospitalized near their families and homes, in hospitals in which their own-local-doctors have hospital 
findings seems less predicated on the weight of the evidence before it than on its insistence on an extraordinary degree of certainty in the government's proof. In addition, confusion engendered by the cluster market approach to product market definition contributed to the court's faulty analysis.

Like the Eighth Circuit, the district court in Mercy Health faulted the government for failing to apply a dynamic analysis in proving a relevant geographic market. 146 For example, the court disputed the DOJ's reliance on patients' reluctance to switch physicians, noting that a more fluid analysis would address future patient responses to financial incentives. ${ }^{147}$ By way of contrast, the court cited instances of successful patient recruitment by outreach clinics sponsored by the regional hospitals. 148 The court also considered the numbers of patients residing in zip codes within twenty-five miles of Dubuque traveling to distant hospitals and the success that certain doctors and third-party payors had in using financial incentives to get patients to choose more distant hospitals for tertiary or elective services. 149

The court's criticism that the government's case "rests too heavily on past health care conditions" 150 is puzzling. In contrast to the FTC's limited proof in Freeman Hospital, the Antitrust Division put forward a variety of subjective and objective evidence designed to provide the kind of dynamic analysis the Eighth Circuit had found lacking. ${ }^{151}$ Some of this evidence was simply ignored in the district court's opinion, 152 while other proof was dismissed for want of corroboration ${ }^{153}$ or based on rebuttal evidence of questionable probative value.154 Like the court of ap-

privileges. ... [Defendants' proposal] is ridiculous-a ten county area in which it is assumed (without any evidence and contrary to common sense) that Rockford residents, or third party payors, will be searching out small, obscure hospitals in remote rural areas if the prices charged by the hospitals in Rockford rise above competitive levels.

898 F. 2d 1278, 1285 (7th Cir. 1990).

146 See Mercy Health, 902 F. Supp. at 978 . Proof of where patients could practically go "requires a fluid analysis. It is not sufficient to take a snapshot of the current situation and define the relevant geographic market to be synonymous with the current service areas of the defendant hospitals." Id.

147 See id. at $978-79$.

148 See id. at 979.

149 See id. at 979-80.

150 See id. at 978.

151 See id. at $977-83$.

152 The court refused to accept the government's proof that geographic price discrimination, such as raising prices to managed care enrollees within the city, could result from the merger. See id. at 981 .

153 See id. at 981.

154 The court relied on past experience in which patients traveled to regional hospitals for certain services. See id. However, the services received were for the most part not available in $\mathrm{Du}$ buque or not even part of the acute care in-patient product market, such as elective plastic surgery. See Combined Reply/Response Brief of the United States at 8-9, United States v. Mercy Health Servs., 107 F.3d 632 (8th Cir. 1997) (Nos. 95-4253, 96-1051). By generalizing from experiences involving obviously dissimilar circumstances and disparate, highly differentiated service markets, the court appears to have engaged in clearly erroneous reasoning. In addition, the court seemed persuaded by evidence that financial incentives from managed care organizations had induced some patients to choose regional hospitals for specific care; for example, some witnesses suggested that payments of \$200-1000 would induce patients to travel distances to receive nonsurgical cancer treatment or heart care. See Mercy Heallh, 902 F. Supp. at 982 . This evidence however does not negate the substantial evidence that individuals would not buy insurance contracts with managed care requirements that would remove all local options for care. Even if point of service plans were offered, the potential switching for certain services would pose no credible threat to a dominant local hospital on which subscribers would still depend for their local needs. 
peals in Freeman Hospital, the district court seemed to require a degree of certainty from the government's evidence on the dynamic issue, discounted opinion testimony of the most knowledgeable market participants and favored questionable hard evidence that was based on experiences of dubious probative value in answering the ultimate question. ${ }^{155}$ In addition, the court relied on evidence of dubious value-i.e., that some Dubuque area citizens used distant hospitals-to draw the inference that switching was likely to occur in the event of a small but significant increase in price and hence to broaden the geographic market.156 As discussed above, given the substantial number of factors that make choice of hospital highly idiosyncratic, such inferences seem misplaced.

Though the court did not spell out its conclusions regarding the sufficiency of the evidence in terms of the parties' burdens, one may draw several conclusions. It would appear that the government at least satisfied its burden of persuasion on the geographic market issue, including the dynamic issue. The leading third-party payors testified about the necessity of including a Dubuque hospital in order to sell policies to subscribers, causing the government to reject the possibility that remote hospitals could form an effective substitute. 157 Physician testimony supported this analysis. ${ }^{158}$ Further, the government's expert analysis of historical patient-origin data also gave at least indirect evidence of what patient preferences would be in the event of higher prices in the future. 159 Evidently, the court concluded that defendants successfully rebutted the government's evidence by presenting proof of historical switching in response to financial incentives, the use of financial incentives to induce patient travel over some distance and the successful patient recruitment by outreach clinics.160 It should be noted that the court's analysis of the dynamic question never addressed the possibility that the Dubuque hospital market was already performing in a less than competitive manner. If, as may well have been the case, ${ }^{161}$ the market was not competitive before the merger, the opinions of market participants about how they would respond to future increases above prevailing prices and even limited evidence of past switching by consumers would be of limited value in defining an appropriate geographic market because of the "Cellophane fallacy"

155 See id. at $987-88$.

156 For example, the court stressed evidence of travel to distant markets for services that were not a part of the product market, patient shifting with an extremely limited number of patients and evidence that certain physicians shifted patients away for nonfinancial reasons. See id. at 981 .

157 See id.; United States' Brief at 12-17, Mercy Health (Nos. 95-4253, 96-1051).

158 See United States' Brief at 11-12, 15, Mercy Health (Nos. 95-4253, 96-1051).

159 See Mercy Health, 902 F. Supp. at 978-80. The government also adduced evidence addressing the quantity of switching (the "critical loss ratio") necessary to defeat supracompetitive pricing after the merger. See id. at 981 . According to the government's expert witness, this evidence tended to prove that an extraordinary number of individuals ( $46 \%$ of all managed care patients) would have to be willing to pass up local hospitals and travel 70-100 miles. See id. However, the court specifically rejected the government's contention that such a degree of switching would not occur, finding that it rested on erroneous assumptions regarding the strength of patientphysician loyalty and the willingness of persons within 25 miles of Dubuque to switch to hospitals outside Dubuque. See id.

160 See id. at $981-82$.

161 The court found the merging hospitals found little significant competition except for the regional hospitals located $60-70$ miles away, see id. at 982 , but made no specific findings about the pre-merger intensity of competition in the market. And indeed, defendants contended that the merging hospitals "[had] not competed vigorously in the past." See Brief of Appellees/CrossAppellants Mercy Health Services and Finley Tri-States Health Group, Inc. at 3, Mercy Health (Nos. 95-4253, 96-1051). 
problem discussed above. ${ }^{162}$ However, the government failed to address this issue, probably out of the tactical concern that arguing that the Dubuque market was not competitive before the merger would add credence to defendants' argument that the merging hospitals were not close substitutes.

Notably, the court refused to credit the not-for-profit status of the hospitals as grounds for approving the merger. ${ }^{163}$ In addition, it rejected the efficiencies defense proposed by defendants, questioning the magnitude of the claimed efficiencies. 164 The court also noted that many of the claimed efficiencies could be attained without the merger while others might not be achievable as claimed by the parties. ${ }^{165}$ These holdings are consistent with prior case law, but stand in stark contrast to the conclusions reached by the district court in Butterworth, discussed next.

\section{Federal Trade Commission v. Butterworth Health Corp.}

The decision of the district court in Federal Trade Commission v. Butterworth Health Corp. ${ }^{166}$ is the most revolutionary hospital merger decision yet issued. Despite finding that the merger created a surviving entity with market power (in fact, with near-monopoly status) in two relevant markets, the district court refused to enjoin the transaction preliminarily. 167 The opinion opens new vistas for antitrust analysis of hospital mergers by crediting the nonprofit status of the merged hospital and the parties' prospective commitments as a basis for overcoming the presumption of illegality.

The case involved the merger of the two dominant general acute care hospitals in Grand Rapids, Michigan: Butterworth Health Corporation and Blodgett Memorial Medical Center.168 Both are nonprofit corporations and are prosperous, well run hospitals operating well above the level of minimum efficient scale. 169 The merger grew out of Blodgett's interest in building a $\$ 187$ million replacement facility in a more desirable location. ${ }^{170}$ After this proposal met opposition from a local commission set up to study the matter, the parties commenced merger discussions. ${ }^{171}$ Recognizing the antitrust problems associated with the proposed transaction, the parties tried unsuccessfully to secure passage of a state statute immunizing the merger. ${ }^{172}$

162 See supra notes 51-53 and accompanying text.

163 See Mercy Health, 902 F. Supp. at 989.

164 The defendant had claimed over $\$ 2.1$ million in savings would result from "best practices," i.e., improving efficiency in utilization and avoidance of duplication of expenses. The court doubted that the merger was necessary to accomplish these goals given the ready availability of information from a myriad of sources that would accomplish similar purposes. See id. at 988.

165 See id. at $988-89$.

166946 F. Supp. 1285 (W.D. Mich. 1996).

167 See id. at 1302-03.

168 See id. at 1288.

169 See id.

170 See id. at $1288-89$.

171 The Kent County Area Health Care Facilities Commission concluded that existing hospital space for inpatient services was sufficient and suggested that Blodgett consider "reorganizing its present facilities onsite, consolidating inpatient services with other area hospitals and/or moving appropriate ambulatory and support services offsite." Id. at 1289.

172 See David Burda \& Mary Chris Jaklevic, Promises, Promises: Hospitals Are Using Price Control Pledges to Win Antitrust Clearance from States, But the Feds are Wary, MoD. HealthCARE, Feb. 19, 1996, at 26, 26. 
The district court agreed with the FTC's relevant product and geographic markets. ${ }^{173}$ Notably, the court identified two product markets: (1) the general acute care inpatient hospital services market (essentially the same market accepted by courts in several recent hospital merger cases); and (2) a market consisting of primary care inpatient hospital services. 174 This second market includes basic services available at most general acute care hospitals such as normal childbirth, gynecology, pediatrics, general medicine and general surgical services. ${ }^{175}$ This market provides a helpful step forward in refining hospital merger analysis. Disaggregation of the cluster of products reduces the confusion, discussed above, that results when courts attempt to delineate geographic markets for the varied services comprising the cluster. Moreover, in most markets, it probably better reflects market realities in that buyers frequently will segregate purchases of sophisticated services from others for which patients would be willing to travel longer distances.

For purposes of analyzing the general acute care inpatient hospital services product market, the court accepted the FTC's proposed geographic market consisting of Greater Kent County, which includes Grand Rapids plus the area encompassed within a thirty-mile radius (Kent County and portions of seven adjoining counties). 176 Four Grand Rapids hospitals, including the merging parties, and five small rural hospitals located outside of Kent County compete in this market.177 For the primary care inpatient hospital services market, the court adopted a smaller geographic area as the relevant market: the "immediate Grand Rapids area" encompassing only Kent County and only the four Grand Rapids hospitals. ${ }^{178}$

The Butterworth district court's treatment of the facts relating to the geographic market issue contrast starkly with that of the court in Mercy Health. Relying heavily on the views of employers and consumers, it found that factors such as preference for local convenience, perceived quality differences and loyalty to local physicians militated against substantial out-migration in the event of supracompetitive pricing. 179 Although characterizing this evidence as "not conclusive," the court determined that the FTC had, for purposes of preliminary injunctive relief, adequately presented the type of dynamic evidence lacking in the Freeman Hospital and Mercy Health cases. ${ }^{180}$ The court rejected speculative evidence and dismissed consumer surveys which it found relied on ambiguous questions and were of suspect reliability. ${ }^{181}$

With respect to market structure, the court found that after the merger Butterworth and Blodgett would control between $47 \%$ and $65 \%$ of the general acute care inpatient market and $65-70 \%$ of the primary care inpatient market. 182 Though only alluded to in the court's opinion, the FTC presented additional evidence tending to establish that the merger would produce a dominant firm capable of exercising market power unilaterally. For example, the evidence demonstrated that the two other

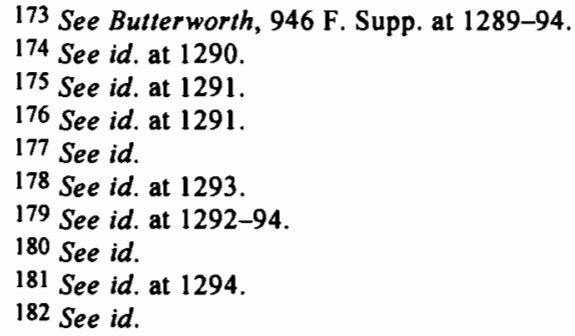


Grand Rapids hospitals were not adequate substitutes for Butterworth and Blodgett 183 and that entry barriers were significant. 184 The evidence also showed that employers and third-party payors believed that they must offer enrollees or employees access to at least one of the merging hospitals 185 and that the merging parties intended to "level the managed care organization playing field" by reducing certain discounts and establishing "standard managed care rates."186 Based on this evidence, the court concluded that there was "no question but that . . . the merged entity would have substantial market power in two relevant markets" and found that the FTC had established a prima facie case. 187

Nevertheless, the court went on to find that the defendants had successfully rebutted both the FTC's prima facie case and the additional evidence of likely harm. Three distinct factors contributed to the conclusion that the proposed merger was not likely to cause anticompetitive effects: the nonprofit status of the hospitals, a community commitment undertaken by the merged entity and efficiencies resulting from the merger. 188 Although the factual premises of each factor can be debated, the court had a plausible basis in the record for each conclusion.

The remainder of this section discusses these factors and their implications for antitrust merger jurisprudence. However, several preliminary observations should be noted. First, as described above, the case law has shifted toward permitting an openended inquiry into the competitive consequences of mergers unaided by meaningful presumptive rules. The effect of this has been to erode the impact of legal doctrine, and make the outcome of litigation highly uncertain. To borrow Judge Easterbrook's criticism of a similarly unhelpful formulation of the rule of reason, "[w]hen everything is relevant, nothing is dispositive."189 Further, these developments have perversely moved antitrust enforcement in a decidedly regulatory direction. Courts and some enforcement agencies increasingly approve market power-enhancing mergers conditioned on monetary payments directed at solving various health policy objectives, or conduct-oriented remedies that will purportedly fix competitive problems by regulating the parties' behavior. 190

183 See id. at 1298 (finding that "the greater range of services and the perceived higher quality of care at defendant hospitals" would limit St. Mary's and Metropolitan's ability to compete with the merged entity).

184 See id.

185 See Proof Brief For Plaintiff-Appellant Fed. Trade Comm'n at 7-8, Federal Trade Comm'n v. Butterworth Health Corp., No. 96-2440 (6th Cir. argued June 9, 1997) (citing trial record); see also Butterworth, 946 F. Supp. at 1309 (reprinting defendants' Exhibit $A$ which stated that the consolidation activities and facilities plan may be adjusted to improve clinical services and patient access to the merged hospital).

186 See Butterworth, 946 F. Supp. at 1299.

$187 \mathrm{Id}$. at 1302. The court concluded that the two small hospitals in Grand Rapids, St. Mary's and Metropolitan, would not be able to compete with the merged entity because of the greater range of services offered by Blodgett and Butterworth and that their ability to defeat a small but significant price increase by the merged entity "would be limited, especially for the foreseeable future." See id. at 1298 .

188 See id. at 1302.

189 See Frank H. Easterbrook, The Limits of Antitrust, 63 TEX. L. REV. 1, 12 (1984).

190 See supra note 59 and accompanying text; see also Butterworth, 964 F. Supp. at 1303 (ordering parties to follow consent decree incorporating "community commitment" terms). 


\section{B. ANALYSIS}

\section{Nonprofit Status of the Merging Hospitals}

Although two circuit courts of appeal, ${ }^{191}$ the district court in Mercy Health192 and the FTC 193 had refused to do so in prior hospital merger cases, the Butterworth court justified its approval of the merger in part based on the nonprofit status of the merging hospitals. 194 In the court's view, the evidence supported the contention that market-share and concentration data do not reliably predict the performance of nonprofit hospitals. First, relying on economic literature and testimony concerning the behavior of not-for-profits both in general and in Michigan, the court found that nonprofit hospitals operate differently in highly-concentrated markets than do profitmaximizing firms. ${ }^{195}$ Specifically, they tend to charge lower prices in more concentrated markets - exactly opposite the pattern on which the presumption of illegality is premised.196 The FTC asserted in its appeal that the district court committed legal error by taking the nonprofit status of defendant hospitals into account. 197 This argument is mistaken. The district court's analysis of the implications of the hospitals' nonprofit orientation and governance structure, though certainly debatable, ${ }^{198}$ seems well within the parameter set out in the Supreme Court's General Dynamics decision. 199 The essence of the court's conclusion was that this particular governing structure had so repositioned the entity's economic incentives as to negate the risk of supracompetitive pricing. Seen from this perspective, the court appropriately con-

191 See Federal Trade Comm'n v. University Health, Inc., 938 F.2d 1206, 1225 (11th Cir. 1991); United States v. Rockford Mem'l Corp., 898 F.2d 1278, 1286 (7th Cir. 1990).

192 See United States v. Mercy Health Servs., 902 F. Supp. 968,989 (N.D. Iowa 1995). Two district courts gave some weight to the nonprofit status of merging hospitals after cursory analysis, but both approved the mergers on other grounds. See Federal Trade Comm'n v. Freeman Hospital, 911 F. Supp. 1213, 1226-28, aff'd, 69 F.3d 260, 273 (8th Cir. 1995); United States v. Carilion Health Sys., 707 F. Supp. 840, $847-49$ (W.D. Va.), aff'd on other grounds, 892 F. 2d 1042 (4th Cir. 1989).

193 See In re Hospital Corp. of Am., 106 F.T.C. 361, 502 (1985), aff'd, 807 F.2d 1381, 1393 (7th Cir. 1988).

194 See Butterworth, 946 F. Supp. at 1297.

195 See id. at 1296-97. The court relied on expert studies showing that high market concentration among nonprofit hospitals does not cause higher prices and, in fact, may result in lower prices. See id. (citing William J. Lynk, Nonprofit Hospital Mergers and the Exercise of Market Power, 38 J.L. \& ECON. 437, 459 (1995)); see also Thomas J. Hoerger, 'Profit' Variability in For-Profit and Not-For-Profit Hospitals, 10 J. HEALTH ECON. 259 (1991) (proposing two tests to evaluate the hypothesis that not-for-profit hospitals behave differently than for-profit hospitals).

196 See Butterworth, 946 F. Supp. at 1296-97.

197 See Brief for Fed. Trade Comm'n at 24, Butterworth (No. 96-2440).

198 The FTC strenuously asserted that Dr. Lynk's analysis is flawed because it fails to hold constant cost differences among hospitals. See Butterworth, 946 F. Supp. at 1296 . Lower prices in concentrated markets may really reflect the fact that rural hospitals tend to have lower costs and compete in less highly concentrated markets. See Brief for Fed. Trade Comm'n at 32-33, Butterworth (No. 96-2440).

199 See United States v. General Dynamics Corp., 415 U.S. 486, 498 (1974) (holding that statistics on market share and concentration are not conclusive indicators of anticompetitive effects and that forward-looking evidence may enable the court to discount the inferences drawn from such data); see also United States v. Brown Univ., 5 F.3d 658, 678 (3d Cir. 1993) (holding that noneconomic objectives of nonprofit defendants required full-scale rule of reason analysis for competitive effects of challenged practices). 
sidered evidence that concentration and market-share data paint a misleading picture in view of special economic forces at work in this market. ${ }^{200}$

One may nevertheless question whether the district court in Butterworth undertook the kind of forward-looking analysis of market conditions that General Dynamics mandates. For example, the opinion pays scant attention to evidence that changing market conditions in the Grand Rapids market were forcing greater price concessions as pressure from managed care intensified.201 Hence, evidence of historical price/concentration correlations themselves needed to be viewed dynamically and perhaps discounted where the evidence suggested that changing competitive pressures may in the future tend to reverse nonprofit hospitals' behavior patterns.

\section{Governance Structure of the Merged Hospital}

The second implication the court drew from the merged hospital's nonprofit status was that, despite its market power, the hospital would operate benignly because of its governance structure. ${ }^{202}$ Noting that the merged hospital would be "comprised of community business leaders who have a direct stake in maintaining high quality, low cost hospital services,"203 the court apparently concluded 204 that these individuals would help check any price-elevating tendencies attributable to the hospitals' dominant market position.205 Again, the defendants raised a cognizable issue about the reliability of inferences drawn from market concentration and market share data. It is certainly possible that a business enterprise can be organized in a

200 While rejecting similar claims in Rockford because they were premised on theoretical guesses, Judge Posner left open the possibility of accepting such a defense where defendants could offer studies and empirical evidence to support the presumption that high concentration among nonprofit hospitals does not result in higher prices. See United States v. Rockford Mem'1 Corp., 898 F.2d 1278, 1286 (7th Cir. 1990).

201 For example, the FTC offered a wealth of evidence from internal planning documents and other sources demonstrating that Blodgett and Butterworth recognized that increased competitive pressures were forcing them to lower prices and adopt cost-control strategies. See Brief for Fed. Trade Comm'n at 28-30, Butterworth (No. 96-2440). Moreover, several studies of markets with considerably longer experience with competitive pressures than Michigan have found that price and concentration were positively correlated. See David Dranove et al., Is Hospital Competition Wasteful?, 23 RAND J. ECON. 247, 247-48 (1992) (using a third-party study to reexamine the hypothesis that hospitals compete by providing too many high-tech hospital services, and concluding that the extent of a market, proximate population and distance to markets predict the pattern of service provision); David Dranove et al., Price and Concentration in Hospital Markets: The Switch from Patient-Driven to Payer-Driven Competition, 36 J.L. \& ECON. 179, 187, 201 (1993) (discussing a study of price changes received by private hospitals in California for the treatment of privately insured inpatients, and finding that profit margins are lower where local market concentration is lower); Glenn A. Melnick et al., The Effects of Market Structure and Bargaining Position on Hospital Prices, 11 J. HEALTh ECON. 217, 229 (1992) (discussing the results of a study of the Blue Cross of California PPO network which found that less competitive markets engender higher prices); see also Vita et al, supra note 75 , at 78 (stating that a hospital's ability to exercise market power decreases if consumers perceive other local hospitals as economic substitutes); Jack Zwanziger et al., Hospitals and Antitrust: Defining Markets, Setting Standards, 19 J. HeAlTH POL. Pol'y \& L. 423, 428-29 (1994) (noting that the more hospitals within an insurer-dominated market are able to offer comparable services and quality, "the more imperative it becomes that [they] be competitive in price").

202 See Butterworth, 946 F. Supp. at 1297.

203 See id. at 1296.

204 The court cited approvingly Dr. Lynk's contentions that hospitals with such governance structures were analogous to consumer cooperatives and lacked incentives to raise prices to monopoly levels. See id.

205 See id. at 1297. 
manner that will insulate the public from the risk of supracompetitive pricing, as, for example, may be the case with consumer cooperatives. 206 However, whether consumer representation on the board of directors will deter supracompetitive pricing is far from certain given the roles that board members play in most corporations. First, outside members of boards of directors (i.e., those who are not also officers or managers) of sizable business enterprises, particularly nonprofit corporations, rarely involve themselves in day-to-day business decisions like pricing policies and discounting practices. ${ }^{207}$ Although such supervision is within their powers as directors, it is still inaccurate to assume that such oversight will occur more likely than not. Consequently, requiring evidence that the board can and will exercise such oversight seems warranted. Second, even where a sufficient number of outside directors undertake such supervision, it is well established that they must act in the interests of the corporation on whose board they serve. Corporate law imposes fiduciary duties of loyalty, care and obedience on boards of nonprofit and for-profit corporations, and these duties preclude conflicts of interest, negligent mismanagement and failure to assure fulfillment of the entity's charitable purposes. 208 In the case of a nonprofit hospital with a charitable mission, an outside director insisting on low consumer prices may in some circumstances be in conflict with one or more of these duties.

In sum, the court in Butterworth raised important issues regarding the implications of nonprofit status and governance on the future competitive dynamics in hospital markets. To have decisional significance in litigation, these issues require clearer analysis and more precise findings than the Butterworth court made, but they are at least fair game for future resolution. In any event, the court made clear that its conclusions regarding the nonprofit status of hospitals were "not a dispositive consideration"209 and proceeded to rely on the dubious grounds discussed below.

\section{Defendants' "Community Commitment"}

The court's conclusion that the merged hospital would benignly exercise its market power relied heavily on a promise by the hospitals to hold down future prices evidenced by a written "community commitment" made binding by consent decree.210 This commitment requires that the merged hospitals freeze list prices or charges, freeze prices to managed care plans at premerger levels, limit profit margins, serve the underserved and medically needy and assure continued consumer representation in the governance structure of the merged entity.211 Though not formally part of their community commitment, the merging parties also made it clear that they planned to eliminate selective discounting to MCOs presumably to eliminate the alleged unfairness of cost shifting. ${ }^{212}$ The court concluded that the hospitals' plan to

206 See id. at 1296.

207 See Robert W. Hamilton, Reliance and Liability Standards For Outside Directors, 24 WAKE FOREST L. REV. 5, 9 (1989) (observing that "[m]odern boards of directors have practically nothing to do with the day-to-day business of the corporation"); see also FURROW ET AL., supra note 48, $\S 5-2$, at 257-61 (describing for-profit corporations); id. $\S 5-11$, at 292-94 (outlining distinguishing characteristics of nonprofit corporations); id. $\S 5-12$, at 295-96 (describing nonprofit corporate governance); DANiEl L. KURTZ, BOARd Liability: GuIDE FOR NONPROFIT DiReCtORS 6 (1988) (describing distinctive features of nonprofit boards).

208 See FURROW ET AL., supra note 48, \$§ 5-14 to -17, at 297-306.

209 See Butterworth, 946 F. Supp. at 1297.

210 See id. at 1303.

211 See id. at 1298.

212 See id. at 1299. 
establish standard managed care rates and to stop giving discounts to some consumers and recouping those discounts by shifting costs would benefit consumers. ${ }^{213}$

Acceptance of these commitments as an adequate safeguard against anticompetitive harm is remarkable in several respects. First, in effect the district court engaged in rate regulation, and did so on an evidentiary record devoid of information or projections about future prices, costs or quality changes in the hospital industry. Rate regulation of hospitals, even by fully staffed administrative agencies, has not proven effective. ${ }^{214}$ Moreover, the myriad of difficulties inherent in prospective rate setting is compounded by the rapid changes occurring throughout the industry. 215 In a similar vein, several state attorneys general have conditioned approval of mergers on monetary settlements predicated on promised efficiency savings. 216 These approaches, which come under increasing critical scrutiny, are highly problematic because of the quandaries associated with regulating efficiencies through litigation. 217

Second, the commitments themselves provide no assurance that consumers will not be harmed by diminution of nonprice aspects of care such as quality, amenities and waiting times. ${ }^{218}$ Third, and perhaps most remarkably, the court endorsed the merging parties' plan to stop granting discounts to MCOs.219 Terming these discounts as "hardly the sort of benefit the antitrust laws are designed to protect," Judge McKeague adopted a static view of the market, apparently assuming that discounts to one group of buyers comes at the cost of higher prices to others. 220 In contrast, economists view price discrimination as supplying an important function, especially in markets undergoing change, essentially providing the mechanism by which prices are ratcheted down. 221

\section{Efficiencies}

The district court accepted defendants' showing of cost savings attributable to the merger as an additional factor contributing to its conclusion that the merger would on balance not have anticompetitive effects. ${ }^{222}$ Though controversy surrounds the wisdom of attempting to quantify and balance efficiencies against potential

213 See id.

214 See John J. Antel et al., State Regulation and Hospital Costs, 77 REV. ECON. \& STAT. 416, 420-22 (1995).

215 See id.

216 See Pennsylvania v. Capital Health Sys. Servs., No. Civ.A.4:CV-95-2096, 1995 WL 787534, at *2 (M.D. Pa. Dec. 15, 1995); Greaney, supra note 59, at 487-88 (describing highly prescriptive consent decrees in Massachusetts and Pennsylvania).

217 See generally Greaney, supra note 59, at 475-82 (discussing efficiency's role in the DOJ/FTC Health Care Policy Statements, which are used to evaluate potential antitrust litigation).

218 See Federal Trade Comm'n v. Butterworth Health Corp., 946 F. Supp. 1285, 1298-99 (W.D. Mich. 1996).

219 See id. at 1298-1300.

220 See id. at 1299.

221 There is a great deal of literature applying this analysis to criticize anti-price discrimination aspects of antitrust law, such as the Robinson-Patman Price Discrimination Act, 15 U.S.C. $\$ \S 13-$ 13b, 2 la (1994). See, e.g., Amold Celnicker, A Competitive Analysis of Most Favored Nations Clauses in Contracts Between Health Care Providers and Insurers, 69 N.C. L. REV. 863, 884-91 (1991) (summarizing criticisms of the Robinson-Patman Act, but explaining the much greater anticompetitive effects of most favored nations clauses).

222 See Butterworth, 946 F. Supp. at 1301. 
harms, ${ }^{223}$ many lower courts routinely consider efficiencies either as an affirmative defense or as part of their overall assessment of competitive effects. 224 However, instead of evaluating claimed efficiencies and weighing them against competitive risks and explaining how they would improve competition, the court merely relied on the greater efforts and experience of defendants' expert witnesses and its own impressions based on a tour of the merging hospitals to conclude that significant capital avoidance and operating efficiencies (in excess of $\$ 100$ million) would be realized.225 Given the parties' community commitment and the nonprofit status of the merged entity, the court concluded that these benefits would be passed on to consumers. 226

The court's candid acknowledgment that measuring efficiencies was an extremely uncertain undertaking, 227 coupled with its willingness to adopt a figure proposed by defendants without elaborating a rationale for doing so, exemplifies the risks inherent in applying modern antitrust merger jurisprudence in cases of this kind. The result is more troubling because in evaluating the claims of efficiencies as part of defendants' rebuttal evidence rather than as an affirmative defense, the court evidently concluded that case law requiring clear and convincing evidence was not applicable. ${ }^{228}$ Casual empiricism of this kind empowers courts to decide cases with highly imperfect factual records in their attempt to answer questions that many experienced antitrust authorities and economists assert are beyond the capacity of judicial fact finding in the first place. In such circumstances, unchecked judicial discretion looms as a serious threat.

223 See, e.g., Robert H. Bork, The ANTITrust Paradox: A POLICY at War WITH ITSELF 127 (1978); Joseph F. Brodley, Proof of Efficiencies in Mergers and Joint Ventures, 64 ANTITRUST L.J. 575 (1996); Fisher \& Lande, supra note 10, at 1592; Joseph Kattan, Efficiencies and Merger Analysis, 62 ANTITRUsT L.J. 513 (1994); Robert Pitofsky, Proposals for Revised United States Merger Enforcement in a Global Economy, 81 GEO. L.J. 195 (1992). The seminal thinking in this area is found in the scholarship of Oliver E. Williamson. See, e.g., Oliver E. Williamson, Economies as an Antitrust Defense Revisited, 125 U. PA. L. REV. 699 (1977).

224 Most courts have rejected the defense, finding the claimed efficiencies could be achieved by means other than merger, were not adequately proved or were not significant net efficiencies once the costs of attaining those efficiencies were offset against the claimed savings. See, e.g., Federal Trade Comm'n v. University Health, Inc., 938 F.2d 1206, 1223 (11th Cir. 1991); United States v. Mercy Health Servs., 902 F. Supp. 968, 987-89 (N.D. Iowa 1995). Courts, however, have accepted efficiencies claims. See, e.g., United States v. Carilion Health Sys., 707 F. Supp. 840, 849 (W.D. Va.), aff'd on other grounds, 892 F.2d 1042, 1042 (4th Cir. 1989).

225 See Butterworth, 946 F. Supp. at 1301.

226 See id.

227 After setting forth the parties contentions regarding efficiencies, the court stated: "Because measuring the efficiencies of a proposed transaction is inherently difficult and because both sides' estimates are clearly based in some measure on speculative self-serving assertions . . . the Court finds it neither appropriate nor necessary to engage in a detailed evaluation of the competing views." Id.

228 See id. at 1301 (describing Butterworth's successful rebuttal of the FTC's prima facie case, thus creating a presumption of legality). But cf. United States v. Rockford Mem'l Corp., 717 F. Supp. 1251, 1291 (N.D. Ill. 1989) (holding that the defendants failed to demonstrate clearly and convincingly that the merger would create a net economic benefit for the health care consumer). See generally AREEDA \& TURNER, supra note 11, Tा 939-62, at 146-99 (addressing the legal and practical implications of courts recognizing an economics or efficiencies defense to allegations of unlawful mergers). 


\section{CONCLUSION}

This Article has argued that those concerned about the drift in antitrust law toward standardless inquiries in merger cases may find their worst fears realized in the hospital merger cases. Left to "ramble through the wilds of economic theory,"229 some courts have exhibited an alarming tendency to reach results that a legal realist may conclude reflects their political or social preferences more than a reasoned parsing of the economic facts before them. 230

229 See United States v. Topco Assocs., Inc., 405 U.S. 596, 622 (1972) (Burger, C.J., dissenting) (asserting that "courts are of limited utility in examining difficult economic problems" and Congress has not yet freed courts to "ramble through the wilds of economic theory in order to maintain a flexible approach").

230 The district court opinions in the Mercy Health, Freeman Hospital and Butterworth cases were all authored by Reagan or Bush appointees. See 1 ASPEN LAW \& BUS., ALMANAC OF THE Federal Judiciary, 8th Cir. Section at 15, 47, 6th Cir. Section at 37 (Megan Chase ed., 1996-2 Supp.). Two members of the Eighth Circuit panel deciding the Freeman Hospital case, including the author of the opinion, were Reagan appointees; the third member was appointed by President Clinton. See 2 aspen Law \& Bus., Almanac of the Federal Judiciary, 8th Cir. Section at 4, 9,11 (Megan Chase ed., 1997-1 Supp.). Empirical analyses of the antitrust decisions show that judges appointed by Presidents Reagan and Bush have been more conservative (i.e., permissive) on antitrust matters including horizontal mergers than those appointed by President Carter. See William E. Kovacic, Judicial Appointment and the Future of Antitrust Policy, ANTITRUST, Spring 1993, at 8, 9; William E. Kovacic, Reagan's Judicial Appointments and Antitrust in the Nineties, 60 FORDHAM L. REV. 49, 53-67 (1991). 